institutions]. Collection of scientific works of Berdyansk State Pedagogical University: pedagogical sciences. Berdiansk, Vol. 2, pp.248250. [in Ukrainian].

6. Navrotskyi, O. I. (2000). Vyshcha shkola Ukrainy $\mathrm{v}$ umovakh transformatsii suspilstva. Monohrafiia [High school of Ukraine in the conditions of transformation of society. Monograph]. Kharkiv, 240 p. [in Ukrainian].

7. Khutorskoy, A.V. (2005). Pedagogicheskaya innovatika - rychag obrazovaniya [Pedagogical innovation - the lever of education]. Online Magazine
"Eidos" 10 september 2005. Available at: http:// eidos.ru/journal/2005/0910-19.htm [in Russian].

8. Shisharina, N. V. (2013). Innovatsii v obrazovanii: sushchnost. funktsii. svoystva i vidy [Innovations in education: essence, functions, properties and types]. Siberian Pedagogical Journal, Vol. 4, pp.45-49. [in Russian].

9. Iarovenko, T. S. (2012). Vydy innovatsii v osviti ta yikh klasyfikatsiia [Types of innovation in education and their classification]. Newsletter of the Dnepropetrovsk University, Vol. 10, Vol. 20, pp.214219. [in Ukrainian].

Стаття надійшла до редакції 15.08.2019

УДК 373.5:37.01-053.6

DOI:

Світлана Булавенко, кандидат педагогічних наук, докторант Інституту проблем виховання НАПН України

\title{
СПІВПРАЦЯ БАТЬКІВ ТА ШКОЛИ ДЛЯ ФОРМУВАННЯ СОЦІАЛЬНОЇ АКТИВНОСТІ УЧНІВ
}

У статті розглядаються особливості взаємодії батьків та школи для формування сочуіальноі активності учнів. Звертається особлива увага на головні завдання співпрачі педагогів і батьків; напрямки, форми та методи роботи з батьками, які є найбільш дієвими. Описана система роботи з батьками для формування сочіальної активності учнів. Автором підкреслюється, що розвиток соиіальної активності можливий лите за умови в єдності всіх освітньо-виховних процесів, які відбуваються в школі та сім'ї, за умови їх взаємодії, взаєморозуміння і взаємоповаги.

Ключові слова: співпрачя батьків та школи; соціальна активність; система роботи з батьками; виховання дітей.

Лim. 7.

Svitlana Bulavenko, Ph. D.(Pedagogy), Doctoral Student of the Institute of Education Problems of the National Academy of Sciences of Ukraine

\section{COOPERATION OF PARENTS AND SCHOOLS FOR FORMATION OF SOCIAL ACTIVITY OF TEACHERS}

The article deals with the peculiarities of the interaction of parents and school for the formation of social activity of students. Special attention is paid to the main tasks of cooperation between teachers and parents; directions, forms and methods of working with parents that are most effective. The system of working with parents for formation of social activity of pupils is described. The author emphasizes that the development of social activity is possible only in the unity of all education and educational processes that take place in school and in the family, provided their interaction, mutual understanding and mutual respect.

The main tasks of the joint activity of teachers and parents: integration of efforts of the family and the pedagogical team in the development of social activity of the child's personality; provision of parental participation in the organization of the educational process and school self-governance; motivation of parents to study scientificmethodical and psychological and pedagogical literature on problems of development and education of children; increasing the psychological and pedagogical culture of parents, replenishing the arsenal of their knowledge, abilities and skills of educational interaction with children; increase the responsibility of parents for raising children, a role of father in family; creation of a system of educational work aimed at improving the legal culture of parents; presentations of successful family education experience; raising awareness of parents and their competence on the problems of healthy lifestyle formation, prevention of asocial behavior and the spread of bad habits, reproductive health of children and youth, organization of meaningful family lifestyle; involvement of parents into educational work with children and youth at the place of residence; provision of psychological and pedagogical support and assistance to problem families.

Directions in working with parents: familiarization with the living conditions of the family, its psychological 


\section{СПІВПРАЦЯ БАТЬКІВ ТА ШКОЛИ ДЛЯ ФОРМУВАННЯ СОЦІАЛЬНОЇ АКТИВНОСТІ УЧНІВ}

climate, peculiarities of the child's behavior; studying the level of pedagogical culture of parents; identification of difficulties experienced by parents; Familiarity with the positive experience of family education in order to spread it; implementation of collective, differentiated and individual pedagogical influence on parents on the basis of careful analysis; assistance to parents in raising their pedagogical culture, an organization of family life as a source of self-education for the child; involvement of parents in participation, an organization of interesting and meaningful extracurricular activities; parental involvement in school management.

Keywords: collaboration of parents and schools; social activity; a system of work with parents; upbringing of children.

П остановка проблеми. Соціальноекономічні та соціально-політичні перетворення, що відбуваються в ураїнському суспільстві, висувають високі вимоги до рівня соціальної активності особистості. Зростання динамічності й мінливості навколишнього соціуму ставить завдання активного включення особистості в перетворювальну взаємодію 3 середовищем та в низку найбільш актуальних завдань соціального становлення суб'єкта суспільного життя. Однак системна криза, яку пережило наше суспільство в 90-х рр. ХХ століття, призвела до підвищення рівня тривожності, поширення фаталістичних установок, загального зниження соціальної активності багатьох груп населення, зокрема й дітей.

Дослідження вчених - психологів, соціологів, філософів, педагогів - показують, що для сучасних школярів властиве пасивне ставлення до життя, відірваність від соціальних проблем, інфантильність, відсутність готовності й прагнення вибудовувати парадигму свого розвитку, вносити посильний вклад в життєдіяльність сім'ї, школи, суспільства в цілому. Індиферентне ставлення до соціальної дійсності, на наш погляд, пояснюється багатьма чинниками, найважливішим 3 яких $\epsilon$ нескоординованість дій педагогів і батьків [4].

Така ситуація створює несприятливі умови для стихійного розвитку соціальної активності дитини й зумовлює необхідність активізації впливу регульованих чинників соціалізації на цей процес, зокрема налагодити співпрацю сім'ї та школи.

Аналіз останніх досліджень. Значний внесок у розробку питань взаємодії сім'ї та школи в процесі виховання дітей зробили П. Блонський, Н. Крупська, А. Макаренко, С. Шацький. Особливу увагу дослідники Л. Балясна, І. Вінниченко, Л. Вовк, О.Киричук, Б. Кобзар, М.Коваль, Ю.Столяров, О. Сухомлинська, Т. Сущенко, Н. Харінко та ін. приділяли розробці теоретичної бази позашкільної та позакласної спільної виховної роботи. Проблема взаємодії сім’ї та школи розглядалась у дисертаційних працях Я. Журецького, Т. Кравченко та інших. У працях Т. Виноградової, Л. Повалій, В. Постового, О. Пухти, О. Хромової та ін. висвітлені теоретико-прикладні аспекти взаємодії сім'ї та школи у вихованні дітей. Однак проблема формування соціальної активності школярів в умовах взаємодії сім'ї та школи досліджена недостатньо.
Метою статті $\epsilon$ ознайомлення 3 особливостями формування соціальної активності учнів в умовах взаємодії батьків і педагогів.

Виклад основного матеріалу. Багатовікова педагогічна практика переконує в тому, що неможливо виховати справжнього громадянина, патріота, трудівника, морально цілісну особистість, якщо в цьому процесі не задіяна родина 3 її традиціями, міжособистісними відносинами, відповідальністю за успіх спільної справи. Сім'я, як абсолютно точно визначає Л.В. Канішевська, це такий тонкий і особливий організм, який здатний не тільки захистити дитину від бід і невдач, від недосконалості навколишнього світу, а й дати ій той моральний стрижень, ту духовну опору, яка забезпечить духовне й фізичне здоров'я, спокійний і врівноважений характер, радісне сприйняття життя, творче ставлення до улюбленої справи [3].

Сім'я являє собою малу соціальну групу, засновану на шлюбному союзі й кровній спорідненості, члени якої пов'язані спільністю побуту, взаємною допомогою, моральною відповідальністю [6]. Сімейний уклад неповторний мікроклімат, стиль внутрішньосімейних стосунків, моральна спрямованість мають неоціненне значення для виховання чутливої до різних впливів і схильної до наслідування дитини.

Сім'я виступає і як середовище, що впливає на дитину, як суб'єкта виховного процесу. Маючи великий виховний потенціал, сучасна сім'я не завжди реалізує його повною мірою.

За даними Державного інституту проблем сім'і та молоді, відповіді респондентів на запитання, наскільки сім'я в українському суспільстві здатна повноцінно здійснювати сімейне виховання дітей, розподілилися наступним чином: повністю здатна - 17\%; скоріше здатна, ніж не здатна - 39\%; скоріше не здатна, ніж здатна - $27 \%$; повністю не здатна $-9 \%$; важко відповісти - 8\%. Таким чином, можемо констатувати, що майже понад $40 \%$ батьків визнають свою неспроможність у виховній сфері [2].

Перешкодами для повноцінного виховання дітей у сім'ї, на думку дорослих, є: брак часу $48 \%$; непідготовленість батьків із педагогічних питань $-29 \%$; нерозуміння важливості виховання дітей родиною - $22 \%$; матеріальні проблеми сім'ї $-12 \%[2]$. 


\section{СПІВПРАЦЯ БАТЬКІВ ТА ШКОЛИ ДЛЯ ФОРМУВАННЯ СОЦАЛЬНОЇ АКТИВНОСТІ УЧНІВ}

Щодо пріоритетів, яким батьки надають перевагу у вихованні: успіхи в навчанні - 36\%; манера поведінки, вміння спілкуватися з іншими людьми - 19\%; статус у колі однолітків - 7\%; здоров'я - 59\%; успіхи у громадський діяльності - 8\%; інтереси, захоплення, уподобання дітей 19\%; вплив друзів, з якими товаришують діти $3 \%[2]$.

Успішне вирішення питань виховання, зокрема формування соціальної активності дітей, можливе тільки при об'єднанні зусиль сім'ї та інших соціальних інститутів. Освітні заклади залишаються важливими соціальними інституціями, які забезпечують виховний процес та реальну взаємодію дитини, батьків та соціуму.

В останні роки в зв'язку з демократизацією суспільства зруйновані старі механізми впливу школи на підростаюче покоління (ослаб педагогічний тиск на учнів, зникла їх заорганізованість), а нові, у зв'язку зі швидкою зміною суспільної формації, знаходяться на стадії розробки. У той же час колись дієві форми та методи, цінності сімейного виховання були забуті. Все вищезгадане призвело до відокремлення певної частини молоді, до створення нею незалежних від дорослих неформальних груп та об'єднань, які, як правило, не кращим чином впливають на підростаюче покоління. У результаті відбулося викривлення життєвих цінностей, а значить, потреб та інтересів, цілей і життєвих планів, сформувався егоїстичний, бездуховний, соціально пасивний тип особистості [4].

Сьогодні виховання як процес має дві взаємопов'язані сторони: активність особистості вихованця, ії діяльність, спрямовану на створення фундаменту свого майбутнього життя, і педагогічно цілеспрямоване управління цією активністю, діяльністю. Сучасна педагогічна наука під активністю особистості розуміє діяльнісне ставлення людини до світу, здатність виробляти суспільно значущі перетворення матеріального і духовного середовища на основі освоєння суспільно-історичного досвіду людства [5]. Соціальна активність - потреба особистості в зміні або підтримці основ людського життя відповідно зі своїм світоглядом, зі своїми ціннісними орієнтаціями, з морально-етичними суспільними установками [2].

Саме в шкільні роки формується здатність особистості до вільного мислення й самостійності, а творча діяльність, в тому числі соціальна, стає реальною особистісною потребою. Цей процес включає в себе усвідомлення дитиною суспільних явищ; розвиток соціальних потреб, що мають громадянську спрямованість, перш за все потреби в колективній взаємодії з однолітками й дорослими та відповідних мотивів, що спонукають до співпраці; участь у практичній діяльності, що має соціально цінну спрямованість як для сім’і, так і для суспільства в цілому [6].

Соціальна активність як стійка риса особистості проявляється в цілеспрямованості, ініціативності, соціальної відповідальності, вимогливості до себе тощо. Це вимагає особливої уваги з боку дорослих і продуманих дій сім’ї та школи в вихованні підростаючого покоління. Усвідомлення єдності громадського та сімейного виховання наштовхнуло нас на думку про необхідність розробки системи заходів, спрямованих на формування механізму взаємодії батьків та педагогів з розвитку соціальної активності учнів. Батьки несуть відповідальність за виховання своїх дітей, але при цьому, на нашу думку, важливо налагодити їх тісну співпрацю зі школою [7].

І.Д. Бех підкреслює, що до тих пір, поки батьки стоять осторонь від школи й не підтримують прямих контактів з нею, школа не має можливості скористатися їх соціальними ресурсами для соціалізації та розвитку соціальної активності особистості [1]. Без тісної взаємодії сім'ї та школи неможлива повна реалізація всіх педагогічних завдань у процесі виховання. Сім'я володіє величезним виховним потенціалом й $є$ основною рушійною силою, здатною впливати на дитину. Щоб цей вплив був вчинений педагогічно грамотно і правильно, вчителю необхідно тісно взаємодіяти з батьками і разом з ними вирішувати поставлені завдання [6]. При цьому необхідно пам'ятати, що взаємодія школи з сім'єю - це не заміна домашнього виховання громадським або навпаки, а їх взаємодоповнюваність у творенні особистості дитини. Ця взаємодія, співпраця повинна виявлятися в усіх видах діяльності.

У батьків та вчителів спільна мета - виховати всебічно розвинену, соціально активну та гармонійну особистість, здатну реалізувати себе в професійному, громадському і сімейному житті. Кінцевим результатом спільної виховної діяльності сім'ї та школи є сформовані в дитини потреби в здоровому способі життя, розвинений інтелект, широкий усебічний розвиток, інтелігентність у спілкуванні, естетичне сприйняття світу, розуміння відповідальності за подальшу долю суспільства та держави, соціальна активність [5].

Досягти цього можливо лише за умови, коли в школі створене й належно функціонує єдине виховне середовище, коли педагоги та батьки поділяють всю відповідальність за майбутнє 


\section{СПІВПРАЦЯ БАТЬКІВ ТА ШКОЛИ ДЛЯ ФОРМУВАННЯ СОЦАЛЬНОЇ АКТИВНОСТІ УЧНІВ}

дитини, коли сім'я та школа діє за принципом єдності слова і діла.

Саме єдності, взаєморозуміння, взаємодії нерідко сьогодні досягти сім’ї та школі досить важко. Протиріччя цієї проблеми походять із того, що загальний освітній рівень батьків неухильно підвищується, а це спричиняє впевненість у непогрішності їхньої педагогічної позиції. Однак практична діяльність педагогів та психологів постійно зустрічається 3 низьким рівнем психолого-педагогічної культури батьків. Окрім того, реалії сьогодення говорять про те, що в родинах погіршується морально-психологічний клімат, часто в сім'ях панує відчуженість між дітьми та батьками, сімейні негаразди стають причиною замкнутості дитини, соціального сирітства, переживань, відчуття власної провини. Саме тому важливо в школі відродити забуту багатьма навчальними закладами форму роботи як всеобуч батьків [2].

Тож головними завданнями спільної діяльності педагогів і батьків є: інтеграція зусиль сім'ї та педагогічного колективу в діяльності щодо розвитку соціальної активності особистості дитини; забезпечення участі батьків в організації навчально-виховного процесу й шкільному самоврядуванні; мотивацію батьків до вивчення науково-методичної та психолого-педагогічної літератури 3 проблем розвитку та виховання дітей; підвищення психолого-педагогічної культури батьків, поповнення арсеналу їх знань, умінь і навичок виховної взаємодії з дітьми; підвищення відповідальності батьків за виховання дітей, ролі батька у родині; створення системи просвітницької роботи, спрямованої на підвищення правової культури батьків; презентації успішного досвіду сімейного виховання; підвищення рівня поінформованості батьків та їхньої компетентності з проблем формування здорового способу життя, профілактики асоціальної поведінки та поширення шкідливих звичок, репродуктивного здоров'я дітей та молоді, організації змістовного сімейного дозвілля; залучення батьків до виховної роботи з дітьми та молоддю за місцем проживання; надання психолого-педагогічної підтримки та допомоги проблемним сім'ям [2].

Сьогодні при формування соціальної активності учнів потрібно активно використовувати потенціал сім'ї, батьки учнів повинні бути не тільки поінформовані про хід навчального процесу, але й активно брати участь у ньому, підтримуючи дитину в реалізації творчих індивідуальних проектів. Слід активно використовувати різні формати публічних звітів про досягнення учнів із залученням батьків; практикувати навчальні завдання, в яких можуть бути використані родинні перекази, історії, реліквії, досвід старшого покоління родини. Разом з батьками повинні розроблятися програми, спрямовані на усвідомлення учнями ролі сім'ї в їх житті та житті їх майбутніх дітей [2].

У межах дослідження в експериментальних навчальних закладах Чернігівської області нами була створена система робота педагогів 3 батьками для формування соціальної активності учнів.

Як показала практика, найбільш дієвими напрямками в роботі з батьками учнів $є$ : ознайомлення 3 умовами життя сім'ї, ¥ї психологічними кліматом, особливостями поведінки дитини; вивчення рівня педагогічної культури батьків; виявлення труднощів, які відчувають батьки; ознайомлення з позитивним досвідом сімейного виховання 3 метою його поширення; здійсненняколективного, диференційованого та індивідуального педагогічного впливу на батьків на основі ретельного аналізу; допомога батькам у підвищенні їхньої педагогічної культури, організації родинного життя як джерела самовиховання дитини; залучення батьків до участі, організації цікавої та змістовної позакласної діяльності; участь батьків в управлінні школою; поширення досвіду роботи з батьками; створення банків науково-методичної інформації 3 проблем сім'ї, сімейного виховання [2].

Були використані такі методи дослідження сім'ї: спостереження; бесіда; тестування; анкетування; діагностика; ділові ігри; аналіз дитячих малюнків про сім’ю; аналіз робіт дітей на творчих виставках; аналіз побажань дітей із скриньки “Довіри”; аналіз творів про сім'ю; індивідуальні співбесіди; демонстрування відеоматеріалів, слайдів, інтернет-сайтів.

У практичній роботі з батьками педагоги використовували колективні й індивідуальні форми взаємодії. Причому в тому й іншому випадку використовуються як традиційні, так і нетрадиційні форми роботи. Традиційними формами роботи 3 батьками були батьківські збори, класні та загальношкільні конференції, диспут, дискусія, презентація досвіду родинного виховання, індивідуальні консультації педагогів, відвідування учнів дома, зустріч батьківської громади 3 адміністрацією школи тощо [2]. Серед нетрадиційних були використані батьківські вечори, батьківські ринги, батьківські тренінги тощо. Варто зазначити, що ключовими фігурами у співпраці навчального закладу з сім'єю є класні керівники. 


\section{СПІВПРАЦЯ БАТЬКІВ ТА ШКОЛИ ДЛЯ ФОРМУВАННЯ СОЦАЛЬНОЇ АКТИВНОСТІ УЧНІВ}

Доцільно організована взаємодія педагогів і батьків здійснювалася поетапно й була спрямована на розвиток активної позиції батьків. Умовою позитивно спрямованої взаємодії стали довірчі відносини між педагогами і батьками. Контакт будувався таким чином, щоб у батьків виник інтерес, потреба домогтися успіху, впевненість в своїх силах. Наслідком такої організації педагогічної взаємодії стала активна участь батьків у вихованні не тільки своєї дитини, але й класу.

А для цього класні керівники, на початку навчального року в межах соціального проекту “Чим ти живеш сім’я?” відвідали родини всіх учнів класу з метою ознайомлення матеріального забезпечення сім’ї та психологічного клімату сім’ї. Батьківські збори - одна з основних форм педагогічного всеобучу батьків, найбільш визнана традиційна форма спілкування з ними. На класних батьківських зборах заслуховувалися повідомлення з різних питань виховання (доповідь, інформація вчителя, лікаря чи повідомлення батьків про досвід виховання дітей у сім'ї), підбивалися підсумки роботи з учнями за семестр, рік; вирішувалися організаційні та господарські питання, аналізувалися питання навчання і виховання учнів, обговорювались шляхи виконання єдиних вимог вчителя і батьків до дітей тощо.

За змістом батьківські збори поділяються на: організаційні (проводяться на початку року); підсумкові (двічі на семестр та в кінці навчального року); збори за тематикою педагогічного всеобучу (вивчення досвіду виховання, ознайомлення з педагогічними рекомендаціями, пам'ятками, алгоритмами, порадами, виставками тощо) [2].

Практикувалося проведення спільних зборів батьків і учнів. Наприклад, коли відчувалося, що не всі діти відповідально ставляться до виконання громадських доручень. У цьому випадку проводився звіт членів самоврядування класу перед учнями і батьками. Говорилося про те, хто й як виконує громадські доручення. Діти розповідали, як вони їх виконують: “Нікіта витівник, кожної перерви придумує й проводить 3 нами цікаві ігри”, “Таня - квітникарка, добре доглядає за квітами” тощо.

Присутні на таких зборах батьки дізнавалися про життя класу, про те, яку роль відіграє їхня дитина в ньому, відчували ставлення до неї однокласників. Учителі не коментували такі звіти: для батьків вони зрозумілі, а діти вчилися аналізувати свою роботу, оцінювати іiі і вчинки товаришів, практично ставитися до себе.
Планувалась робота таким чином, щоб батьки (ніби переходячи з дітьми з класу в клас) засвоювали систематичний курс необхідних знань про виховання дітей в умовах сім'ї, а батьківські збори щоб стали для них уроками родинного виховання. Тематика їх доводилася до відома батьків на організаційних зборах. Щоб привчити батьків до систематичного читання педагогічної літератури, яка сприяє підвищенню їх педагогічної культури, на батьківських зборах практикувалось обговорення актуальних статей і педагогічних ситуацій.

Цікавими для батьків були такі форми проведення батьківських зборів: творчі звіти учнівського колективу перед батьками; родинні зустрічі учнів та батьків відповідно до обраної теми; батьківські збори на лоні природи, батьківський куліш; батьківські збори у формі презентацій сімей, їх традицій, сімейних реліквій, умінь; батьківські збори татусів; батьківські збори у формі прес-конференцій вчителів-предметників із подальшого проведення індивідуальних консультацій по підготовці учнів до закінчення школи тощо.

Вдало проведені збори активізували батьків, тому для успіху в цій важливій справі педагоги вчились формувати громадську думку батьківського колективу. Щоб збори пройшли результативно, їх треба готувати заздалегідь. Для цього підбиралися статті, педагогічні завдання, пропонувалося комусь із батьків поділитись досвідом виховання, готувались необхідні виставки, анкети, пам'ятки, алгоритми тощо. Поточні оцінки, зошити з контрольних робіт та іншу необхідну інформацію про учня класу батькам на парту, за якою сидить їхня дитина. Учителі прагнули зробити спілкування з батьками учнів активним, предметним, живим, різнобічним, позитивним, що й принесло позитивні результати [2]

Окрема сторінка співпраці з батьками - це проведення за участю батьків проектно-пошукової роботи, яка зближує дітей та дорослих, наповнює роботу класів цікавим змістом, залучає батьків учнів до пошуку матеріалів, вивчення з дітьми історичних джерел, архітектурних пам'яток місцевості, де проживають учні, а також написанні творчих робіт та участь в Міжнародному конкурсі “Мій рідний край”.

Вважаємо важливим, щоб педагоги й батьки розуміли один одного, могли взаємодіяти і допомагати один одному, чітко уявляли поставлену мету, завдання та кінцевий результат.

Тож, ефективною та результативною співпрацю педагогів і батьками 3 формування соціальної активності учнів можна вважати тоді, коли: між школою та батьками склалась атмосфера 
співробітництва, взаєморозуміння в досягненні кінцевої мети; коли спілкування педагогів і батьків - це партнерська взаємодія; коли батьки впевнені в професійності педагога, його знаннях; коли склались добрі, довірчі стосунки на основі доброзичливості, щирості, взаємодопомоги та взаємоповаги; коли школа та сім'я - це одна шкільна родина [2].

Висновок. У процесі проведення дослідження співпраці сім'ї та школи ми зробили висновок, що взаємодія педагогів і батьків сприяє розвитку в учнів моральних якостей, готовності і бажання брати участь у громадській діяльності, проявляти відповідальність і старанність. Освітня установа була, є і залишиться, на нашу думку, однією 3 найважливіших соціальних інститутів, що забезпечують виховний процес і реальну взаємодію дитини, батьків і соціуму. Школа зобов'язана допомогти батькам в оволодінні знаннями $з$ питань виховання, організовуючи психолого-педагогічну просвіту, що $є$ важливою умовою взаємодії.

Отже, розвиток соціальної активності як властивості особистості можливий в єдності всіх освітньо-виховних процесів цілісного педагогічного процесу, але перш за все процесів, які були організовані в школі та сім’і, за умови їх взаємодії, взаєморозуміння і взаємоповаги.

\section{ЛІТЕРАТУРА}

1. Бех І.Д. Духовні цінності в розвитку особистості. Педагогіка і психологія. 1997. №1(14). С. 124-129.

2. Булавенко С.Д. Освітньо-інформаційний простір для формування соціально-активної особистості. Навчально-методичний посібник. Ніжин, 2019. 314 с.

3. Канішевська Л. В. Виховання соціальної зрілості старшокласників загальноосвітніх шкілінтернатів у позаурочній діяльності : монографія. Київ, 2011.368 с.

4. Коберник О. М. Управління виховним процесом у загальноосвітньому закладі: монографія. Київ, 2003. 230 с.
5. Кравченко Т. В. Учитель і сім'я: технологія співробітництва. Педагогіка і психологія. 2001. №2. С. $57-64$.

6. Панфилова Л. Взаимодействие семьи и школы: общие проблемы и совместные действия. Директор школьл. 2006. № 6. С. 86 - 92.

7. Пухта О. Співпраця батьків та школи у вихованні дітей. Педагогічний пошук. 2006. № 3(5). C. $74-75$.

\section{REFERENCES}

1. Bekh, I. D. (1997). Dukhovni tsinnosti v rozvytku osobystosti [Spiritual values in the personality's development]. Pedagogy and psychology, No. 1(14), pp. 124-129. [in Ukrainian].

2. Bulavenko, S. D. (2019). Osvitno-informatsiinyi prostir dlia formuvannia sotsialno-aktyvnoi osobystosti [Educational and informational space of forming a socially active personality]. Tutorial. Nizhyn, 314 p. [in Ukrainian].

3. Kanishevska, L. V. (2011). Vykhovannia sotsialnoi zrilosti starshoklasnykiv zahalnoosvitnikh shkil-internativ u pozaurochnii diialnosti : monohrafiia [Education of social maturity of high school students of boarding schools in extra-curricular activities: monograph]. Kyiv, 368 p. [in Ukrainian].

4. Kobernyk, O. M. (2003). Upravlinnia vykhovnym protsesom u zahalnoosvitnomu zakladi: monohrafiia [Management of educational process in a general educational institution: monograph]. Kyiv, 230 p. [in Ukrainian].

5. Kravchenko, T. V. (2001). Uchytel i simia: tekhnolohiia spivrobitnytstva [Teacher and family: Collaboration technology]. Pedagogy and psychology. No. 2, pp. 57 - 64. [in Ukrainian].

6. Panfilova, L. (2006). Vzaimodeystvie semi i shkoly: obshchie problemy i sovmestnye deystviya [Family-school interaction: common problems and joint actions]. Headmaster. No. 6, pp. 86 - 92.[in Russian].

7. Pukhta, O. (2006). Spivpratsia batkiv ta shkoly u vykhovanni ditei [Cooperation of parents and school in the upbringing of children]. Pedagogical search. No. 3(5), pp. 74 - 75. [in Ukrainian].

Стаття надійшла до редакції 21.06.2019

\section{G58080.2058080}

"Боже, дай мені розум і душевний споқій, щоб змиритися з тим, що я не можу змінити; силу, аби змінити те, що можу і мудрість відрізнити одне від одного".

Климентій Шептицький

Блаженний Священномученик

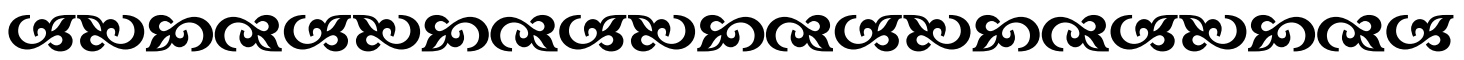

